\title{
Temperature-driven groundwater convection in cold climates
}

\author{
Maria Engström $^{1} \cdot$ Bo Nordell ${ }^{2}$
}

Received: 10 May 2015 / Accepted: 18 April 2016/Published online: 3 May 2016

(C) The Author(s) 2016. This article is published with open access at Springerlink.com

\begin{abstract}
The aim was to study density-driven groundwater flow and analyse groundwater mixing because of seasonal changes in groundwater temperature. Here, density-driven convection in groundwater was studied by numerical simulations in a subarctic climate, i.e. where the water temperature was $<4{ }^{\circ} \mathrm{C}$. The effects of soil permeability and groundwater temperature (i.e. viscosity and density) were determined. The influence of impermeable obstacles in otherwise homogeneous ground was also studied. An initial disturbance in the form of a horizontal groundwater flow was necessary to start the convection. Transient solutions describe the development of convective cells in the groundwater and it took 22 days before fully developed convection patterns were formed. The thermal convection reached a maximum depth of $1.0 \mathrm{~m}$ in soil of low permeability $\left(2.71 \cdot 10^{-9} \mathrm{~m}^{2}\right)$. At groundwater temperature close to its density maximum $\left(4^{\circ} \mathrm{C}\right)$, the physical size (in $\mathrm{m}$ ) of the convection cells was reduced. Small stones or frost lenses in the ground slightly affect the convective flow, while larger obstacles change the size and shape of the convection cells. Performed simulations show that "seasonal groundwater turnover" occurs. This knowledge may be useful in the prevention of nutrient leakage to underlying groundwater from soils, especially in agricultural areas where no natural vertical groundwater flow is evident. An application in northern Sweden is discussed.
\end{abstract}

Maria Engström

maria.engstrom@sweco.se

1 Div. of Hydropower and Dams, Sweco Energuide AB, P.O. Box 50120, SE-973 24 Luleå, Sweden

2 Div. of Architecture and Water, Luleå University of Technology, SE-971 87 Luleå, Sweden
Keywords Groundwater flow - Thermal convection · Numerical modelling · Groundwater density/viscosity · Sweden

\section{Introduction}

Traditionally, fertilizer is applied to fields at different time of the year in the north and in the south of Sweden. It is considered more efficient to apply fertilizer in the autumn in the north, while it is done in the spring in the south. Nutrient loss to groundwater leads to overfeeding of lakes and watercourses, negatively impacting flora and fauna. By understanding the mechanisms behind the leakage, fertilizing could be done more effectively. Such knowledge would also be helpful in preventing and counteracting other types of contamination by leakage from the ground surface to groundwater (Kyllmar 2004). Ground heat exchangers, used for extraction of thermal energy for space heating/cooling, are also affected by such groundwater convection (Hellström et al. 1988).

An approach to understanding the mechanism of nutrient leakage from agricultural land as a result of thermally driven groundwater convection, similar to seasonal mixing of lakes, was suggested by Engström and Nordell (2006). In that study, the groundwater convection was modelled for a groundwater temperature of $10^{\circ} \mathrm{C}$ (southern Sweden), whereby the groundwater convection was initiated by cooling of the uppermost groundwater. This "heated from below" study showed that groundwater convection reaches down to a depth of at least $5 \mathrm{~m}$ when the uppermost groundwater is cooled from 10 to $4{ }^{\circ} \mathrm{C}$. It was found that the penetration depth depends on water temperature, thermal gradient and permeability of the soil.

In the current study, in the north of Sweden, the undisturbed groundwater temperature is below $4{ }^{\circ} \mathrm{C}$. After a long period of ground frost, heating occurs from the ground surface 
during the spring and early summer. The thawing frost front is at a temperature close to $0{ }^{\circ} \mathrm{C}$, while the surface groundwater will warm up until it reaches $4{ }^{\circ} \mathrm{C}-\mathrm{a}$ "heated from above" convective layer is formed. The hypothesis in this is that the seasonal temperature variation initiates and drives thermal groundwater convection, as shown in Fig. 1.

During spring and early summer, heat is transported from the ground surface into the ground. In the north of Sweden, this means that the uppermost groundwater layer is heated from 3 to $4{ }^{\circ} \mathrm{C}$. The heat flow melts the frost further down into the ground; thus, the ground surface and the uppermost groundwater are "warm", while the groundwater at the frost front is at $0{ }^{\circ} \mathrm{C}$. This temperature difference, along with a suitable permeability in the ground and a beneficial soil layer thickness, induces a convective transport of groundwater.

The denser warmer water begins to sink while the colder less dense water below starts to rise and a convection cell is formed. With increasing air temperature, the uppermost groundwater temperature will not remain at $4{ }^{\circ} \mathrm{C}$. While the temperature at the groundwater surface is increasing, a density boundary of $4{ }^{\circ} \mathrm{C}$ water is formed as an upper boundary of the convective layer. Density-driven convection takes place between the $4{ }^{\circ} \mathrm{C}$ density boundary and the thawing frost boundary described in Fig. 2.

Seasonal turnover in lakes is well understood (Kirilin 2010). A stable thermal stratification of lake water occurs during summer and winter as the density of the water increases with depth. This stratification is disturbed during spring and autumn by the density changes resulting from a temperature change, i.e. heating or cooling of the uppermost layer of water. The temperature of the whole lake is temporarily uniform before the temperature distribution is "turned upside down". The driving force of thermal convection is the seasonal temperature variation of the surface water and its temperature dependent density and viscosity.

Lapwood (1948) started the analysis of groundwater convection by describing a number of cases for the onset of convection in porous media. Straus and Schubert (2012) showed that convection patterns were initiated in porous media at the critical Rayleigh number; however, these studies were made for very large convection cells $(\mathrm{km})$ and large temperature differences. Prasad and Kulacki (1984) made basic convection studies for a rectangular porous cavity with constant heat flux on one wall. Simmons et al. (2001) discusses the challenge in describing the onset of natural convection in strongly heterogeneous porous media. Nield and Kuznetsov (2010) describe how convection instabilities develop with time in porous media. The two latter studies are highly relevant to the work reported here.

Conductive heat transport through the soil cover depends on the depth to the water table, the soil thermal conductivity, and the temperature difference between the groundwater and the soil at ground surface (Claesson et al. 1985a). Natural convection in fluid-saturated porous media is well covered in heat transfer literature because of its many engineering applications (Nield and Bejan 1999).

Most studies in saturated porous media with nonlinear density distribution usually consider convection in thin layers, for small-scale industrial filter applications (Vadaz and Olek 1999). Thermal convection in aquifers has been studied at much higher temperatures in large geological formations (Pestov 2000; Cardenas et al. 2012; Krol et al. 2014) and in thermal energy storage in aquifers (Claesson et al. 1985b). The problem reported here involves temperatures up to $10{ }^{\circ} \mathrm{C}$ and convection cells up to a few meters.

Only a few field measurements on thermally driven convection have been found, none in a subarctic climate. Bense and Kooi (2004) showed that, in their study, groundwater temperature was fluctuating $2{ }^{\circ} \mathrm{C}$ at the depth of $0.5 \mathrm{~m}$ below the ground surface; they observed 3.5 oscillations over $100 \mathrm{~m}$. The possibility that such patterns represent groundwater convection was however not discussed in the paper. Krol et al. (2014) investigated heat generated onset of convection cells by injecting heat at high temperature $\left(70^{\circ} \mathrm{C}\right)$ into an aquifer.

There are some previous studies of convection in heterogeneous media but not with impermeable parts embedded into the porous media. Prasad and Simmons (2003) did a numerical study on the onset of convection in heterogeneous porous media. The heterogeneity consisted of Monte Carlo simulated varying permeability in a $(20 \times 150 \mathrm{~m})$ control volume.
Fig. 1 Diagram illustrating how heating or cooling drives groundwater convection. Groundwater mixing reaches greater depths in the south of Sweden since the groundwater mean temperature deviates more from the maximum density water temperature $\left(4^{\circ} \mathrm{C}\right) . Q$ is heat flux

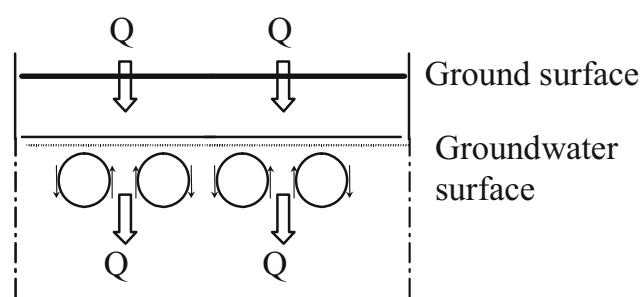

North Sweden, Spring

Groundwater temp. $\sim 3^{\circ} \mathrm{C}$

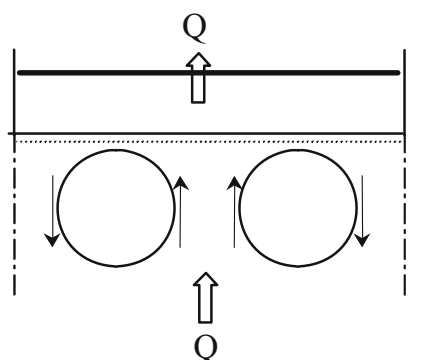

South Sweden, Autumn Groundwater temp. $\sim 10^{\circ} \mathrm{C}$ 


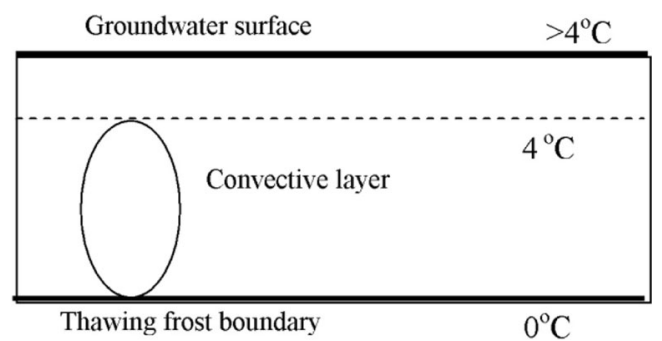

Fig. 2 A boundary is formed between the upper heated surface groundwater and the lower convective layer

\section{Theory of thermal convection}

By changing a fluid's temperature, the resulting density and viscosity change will stimulate motion of the fluid (Rehbinder et al. 1995). This also happens when a permeable material is being saturated with water, e.g. groundwater in soil, even though the porous material slows down the flow velocity of the water.

The fluid's temperature is assumed equal to the matrix's temperature. Heat is transported by convection and conduction in the fluid and by conduction only in the matrix (Ene and Polisevski 1987). The mathematical formulation of thermal convection in porous media, near $4{ }^{\circ} \mathrm{C}$, was provided by Blake et al. (1984). Mass, momentum, and energy for the homogeneous porous medium model are conserved, as described by the following equations (note: terms used in this paper are also presented in the Appendix):

$\frac{\partial u}{\partial x}+\frac{\partial v}{\partial y}=0$

$u=-\frac{K}{\mu} \frac{\partial P}{\partial x}$

$v=-\frac{K}{\mu}\left(\frac{\partial P}{\partial y}+\rho g\right)$

$\sigma \frac{\partial T}{\partial t}+u \frac{\partial T}{\partial x}+v \frac{\partial T}{\partial y}=\alpha\left(\frac{\partial^{2} T}{\partial x^{2}}+\frac{\partial^{2} T}{\partial y^{2}}\right)$

where the variables $u$ and $v$ are the fluid velocity components, $P$ is pressure, $\rho$ is fluid density, $t$ is time, and $T$ is temperature. The constant $K$ is the (intrinsic) permeability of the porous matrix, $\mu$ is the viscosity, $\alpha$ is the thermal diffusivity, and $g$ is the gravitational acceleration. The heat capacity ratio $\sigma$ is defined as

$\sigma=\frac{\phi\left(\rho c_{\mathrm{p}}\right)_{\mathrm{f}}+(1-\phi)\left(\rho c_{\mathrm{p}}\right)_{\mathrm{s}}}{\left(\rho c_{\mathrm{p}}\right)_{\mathrm{f}}}$

where $\varphi$ is the porosity of the medium, $c_{\mathrm{p}}$ is the specific heat at constant pressure, $\left(\rho c_{\mathrm{p}}\right)_{\mathrm{f}}$ and $\left(\rho c_{\mathrm{p}}\right)_{\mathrm{s}}$ are the heat capacity of the fluid and solid matrix respectively. The usual Boussinesq approximation of temperature dependent density cannot be used in this case. The density function of temperature is not linear close to the density maximum; therefore, a better, nonlinear approximation is that of Goren (1966) and Moore and Weiss (1973).

$\rho=\rho_{0}\left(1-\gamma\left(T-T_{0}\right)^{2}\right)$

where $\rho_{0}$ is the maximum density of the water at $T_{0}=3.98{ }^{\circ} \mathrm{C}$ and $\gamma=8 \cdot 10^{-6}\left({ }^{\circ} \mathrm{C}^{-2}\right)$. This approximation is valid in the temperature range of 0 to $10^{\circ} \mathrm{C}$; air pressure fluctuations are not considered to affect the density of water in this study (Franks 1972). Eliminating pressure from Eq. (3), Eq. (4), and incorporating Eq. (6) leads to the single momentum conservation statement.

$\frac{\partial u}{\partial y}-\frac{\partial v}{\partial x}=-2 \frac{K \gamma g}{v}\left(T-T_{0}\right) \frac{\partial T}{\partial x}$

Here the kinematic viscosity $v$ is taken as $\mu / \rho_{0}$. The dynamic viscosity of a fluid $\mu$ is a second order function of temperature between 0 and $10^{\circ} \mathrm{C}$. The viscosity function used was derived from tabled values.

The Rayleigh Number (Ra) is the balance between buoyancy force and viscous force (Kundu 1990). In porous media, Ra can be derived from the system of Eqs. (1)-(7), when Eq. (7) is written in a non-dimensional form. $\mathrm{Ra}$ is a nondimensional constant and an eigenvector in the solution of the non-dimensional systems of equations (Nield and Bejan 1999). Ra can be written as:

$\mathrm{Ra}=\frac{g K \gamma\left(T-T_{0}\right)^{2} H}{\alpha v}$

where $H$ is the depth of the control volume. The general critical Rayleigh number, $\mathrm{Ra}_{\mathrm{c}}=4 \pi^{2}$, indicates that convection occurs when $\mathrm{Ra}>\mathrm{Ra}_{\mathrm{c}}$.

Thermally driven convection could be triggered and partly driven by horizontal groundwater flow, when convection begins at a lower Ra number. This phenomenon has been the subject of detailed studies in the field of aquifer thermal energy storage (Engström and Nordell 2006). Ra was analysed for different boundary conditions and it was shown that it was possible to get lower $\mathrm{Ra}_{\mathrm{c}}$ than the general $\mathrm{Ra}_{\mathrm{c}}=40$ at undisturbed groundwater conditions (Nield and Bejan 1999).

The Nusselt $(\mathrm{Nu})$ number is defined as the ratio between actual heat transfer and conductive heat transfer. For a given geometry one then gets

$\mathrm{Nu}=\frac{Q_{\text {actual }}}{Q_{\text {conductive }}}=\frac{Q_{\text {actual }}}{\frac{k L\left(T_{\mathrm{H}}-T_{\mathrm{C}}\right)}{H}}$

where $k$ is the thermal conductivity of a water-saturated porous matrix while $T_{\mathrm{H}}$ and $T_{\mathrm{C}}$ refer to hot and cold temperature, 
respectively. $H$ and $L$ are depth and length of the control volume, respectively; thus, convective heat transfer entails $\mathrm{Nu}>1$ (Nield and Bejan 1999). In the performed calculations, the converging $\mathrm{Nu}$ was used as a criterion for the stability of the numerical simulations.

\section{Methods}

\section{Objective and scope}

The objective of the current study was to investigate thermally driven groundwater convection with a groundwater mean temperature lower than $4{ }^{\circ} \mathrm{C}$; in this case, the convection starts via heating of the uppermost groundwater. The transient development of the convection cells was modelled.

Some assumptions are made about the natural conditions and also prerequisites for the simulation model. A constant water table close to the ground surface was assumed. The permeability and the thermal conductivity are assumed to be constant in the vertical and horizontal direction. It was also assumed that the driving energy of the convection is the heat transport from the warmer ground surface into the groundwater.

At the upper and lower boundaries, the temperatures are constant. An initial disturbance is necessary to start the convection and an initial horizontal groundwater velocity was therefore introduced. Other natural disturbances such as inclined groundwater surface, air pressure variations, groundwater flow, heterogeneous permeability, and varying thermal conductivity of the soil, are not considered. Melt water or rain infiltration, which would influence the temperature gradient, are not considered in this study.

\section{Simulations}

The software ANSYS Fluent (ANSYS Inc 2014) is specialized to preform computational fluid dynamics (CFD) simulation and uses a control volume technique to solve the equations of the conceptual model. The governing equations of momentum, energy and pressure are integrated and then discretized by a second-order upwind method. The solver is segregated and the interpolation scheme is implicit. The gradient is cell based and absolute velocity is used. When the residuals of energy, continuity and velocity are low enough $\left(10^{-6}\right)$ the solution is considered converged.

A suitable mesh size for the simulations was first determined. Steady-state calculations were then performed to analyse how permeability and leakage depth influenced the formation of convection cells. Transient solutions were used to evaluate the time needed to establish stable convection patterns; additionally, the influence of obstacles (frost lenses or stones) in the soil, on the groundwater convection, was simulated.

\section{Conceptual model}

A two-dimensional (2-D) control volume is filled by a porous material and water. Here, $H(\mathrm{~m})$ is the depth of the control volume and $L(\mathrm{~m})$ is the length of the same (see Fig. 3).Heat is transported across the upper and lower boundaries. In order to idealise the problem, the permeability is assumed equal in both vertical and horizontal directions and the local temperature $T$ is equal in both the porous material and water. The constant boundary temperatures are $T_{\mathrm{H}}=4{ }^{\circ} \mathrm{C}$ and $T_{\mathrm{C}}=0{ }^{\circ} \mathrm{C}$ at the top and bottom of the control volume, respectively. There is no groundwater flow through the control volume, but an initial horizontal velocity $V_{\mathrm{i}}\left(\mathrm{m} \mathrm{s}^{-1}\right)$ is needed to start the convection, which is required by the simulation model but does not affect calculated convection velocities. A grid of quadratic mesh cells was used over the control volume.

Impermeable rectangular obstacles were added in the control volume to make the simulations similar to natural conditions. Two different scenarios were studied. In some simulations such as that of a frost lens, the obstacles had a constant wall temperature $\left(T_{\mathrm{W}}=0{ }^{\circ} \mathrm{C}\right)$, while in other cases, the impermeable obstacle had the same temperature and thermal transfer abilities as the surrounding porous media (stones).

\section{Other assumptions}

Typical porosity values in sand, with grain sizes of $1-5 \mathrm{~mm}$, are $35-50 \%$. To simplify the simulations, the porous material is assumed to consist of spherical grains of equal size, i.e. the porosity is kept constant at $35 \%$. By varying the grain size, the Ra differs due to the permeability change. The (intrinsic) permeability, $K$, as given by Bear (1972) is:

$K=\frac{D_{\mathrm{p}}^{2} \phi^{3}}{180(1-\phi)^{2}}$

where $D_{\mathrm{p}}$ is the grain size and $\varphi$ is the porosity. The dynamic viscosity of the groundwater has been varied

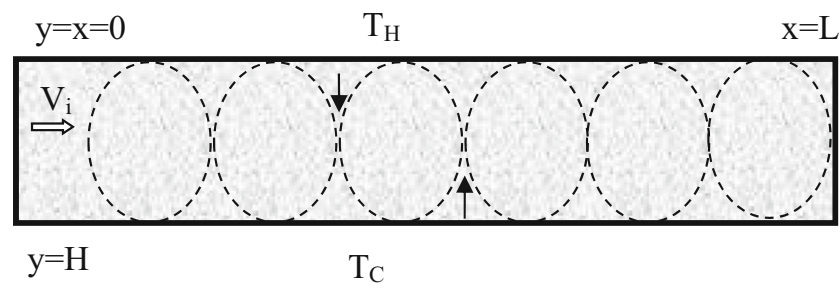

Fig. 3 Vertical section of a control volume with length $L$ and depth $H$. The upper boundary is at constant temperature $T_{H}$, and the lower boundary is at constant temperature $T_{C}$, where $T_{H}>T_{C}$. $V_{i}$ is the initial velocity, and the cells represent the expected pattern 
with temperature according to Franks (1972), from 0.001792 to $0.001308 \mathrm{~kg} \mathrm{~m}^{-1} \mathrm{~s}^{-1}\left(10{ }^{\circ} \mathrm{C}\right)$.

\section{Size of control volume and mesh}

The numerical modelling requires that the length $(L)$ and depth $(H)$ of the analysed groundwater volume is big enough for convection to take place. It also requires that the mesh size is small enough to analyse the groundwater movement. The mesh size of a fixed control volume 5 . $0.5 \mathrm{~m}(L \times H)$ was systematically reduced in small steps from 0.15 to $0.020 \mathrm{~m}$ (see Table 1, part 1). All mesh cells in this simulation are quadratic and the meshing is uniform all over the area. As seen in Table 1 (part 1), $\mathrm{Nu}$ converges (at 1.36) with decreasing mesh size, which thus gives the maximum mesh size as $0.025 \mathrm{~m}$. Subsequently, at least 20 mesh cells in the vertical direction were used to obtain converged solutions in the different control volumes. So, for a control volume of $0.5 \cdot 5.0 \mathrm{~m}, 4,000 \mathrm{mesh}$ cells are used.

Table 1 Summary of numerical results of convection concerning permeability, mesh size and depth of the control volume in the north of Sweden

\begin{tabular}{clllllll}
\hline $\begin{array}{l}L \\
(\mathrm{~m})\end{array}$ & $\begin{array}{l}H \\
(\mathrm{~m})\end{array}$ & $\begin{array}{l}\text { Mesh size } \\
(\mathrm{m})\end{array}$ & $\begin{array}{l}K\left(10^{-9}\right) \\
\left(\mathrm{m}^{2}\right)\end{array}$ & $\begin{array}{l}\text { Grain size } \\
(\mathrm{mm})\end{array}$ & $\begin{array}{l}\mathrm{Ra} \\
(-)\end{array}$ & $\begin{array}{l}\text { Nu } \\
(-)\end{array}$ & $\begin{array}{l}\text { No. of cells } \\
(-)\end{array}$ \\
\hline Part 1 & & & & & & & \\
5 & 0.5 & 0.1 & 6.09 & 3 & 38 & 1.24 & 10 \\
5 & 0.5 & 0.05 & 6.09 & 3 & 38 & 1.41 & 14 \\
5 & 0.5 & 0.025 & 6.09 & 3 & 38 & 1.36 & 18 \\
5 & 0.5 & 0.0125 & 6.09 & 3 & 38 & 1.36 & 18 \\
Part 2 & & & & & & \\
5 & 0.5 & 0.025 & 3 & 6.09 & 38 & 1.36 & 18 \\
5 & 0.5 & 0.025 & 2.5 & 4.23 & 27 & 1.06 & 14 \\
5 & 0.5 & 0.025 & 2 & 2.71 & 17 & 0.7 & 12 \\
5 & 0.5 & 0.025 & 1.75 & 2.07 & 13 & 0.53 & 10 \\
5 & 0.5 & 0.025 & 1.5 & 1.52 & 10 & 0.53 & \\
Part 3 & & & & & & \\
5 & 0.5 & 0.025 & 2 & 2.71 & 17 & 1.12 & 12 \\
5 & 0.6 & 0.025 & 2 & 2.71 & 20 & 1.15 & 10 \\
5 & 0.7 & 0.025 & 2 & 2.71 & 24 & 0.89 & 12 \\
5 & 0.8 & 0.025 & 2 & 2.71 & 27 & 1.08 & 8 \\
5 & 0.9 & 0.025 & 2 & 2.71 & 31 & 1.03 & 8 \\
5 & 1 & 0.025 & 2 & 2.71 & 34 & 0.97 & 8 \\
5 & 1.1 & 0.025 & 2 & 2.71 & 37 & 0.57 & - \\
Part 4 & & & & & & \\
5 & 3 & 0.0025 & 3 & 6.09 & 230 & 0.99 & 6 \\
5 & 1 & 0.0025 & 2 & 2.71 & 34 & 0.97 & 8 \\
5 & 1 & 0.0025 & 1.75 & 2.07 & 26 & 0.84 & 10 \\
5 & 1.5 & 0.0025 & 1.5 & 1.52 & 29 & 0.59 & 4 \\
\hline
\end{tabular}

\section{Critical permeability and penetration depth}

The second part of the analysis was to determine a critical permeability. Four grain sizes were analysed to find the lowest possible permeability for convection to occur. The size of the control volume was kept constant as well as the mesh size (see Table 1, part 2).

The third part considered the penetration depth of the vertical water movement. The control volume contained at least 20 mesh cells in the vertical direction. The vertical depth was varied from 0.1 to $1.0 \mathrm{~m}$, whereas the permeability was kept constant (see Table 1, part 3).

Transient solutions were used to evaluate the time to establish stable convection patterns. The development of the convection was examined at 1 day, 13 days and 22 days; furthermore, the obvious influence of obstacles (frost lenses or stones) in the soil, on the groundwater convection, was simulated. The geometry of the impermeable obstacles was given as an easy-to-apply rectangular shape, whereby these obstacles were assumed to prevent or hinder the convection from occurring. Finally, the question arose as to whether the temperature of the obstacle had any influence on the convection. Two scenarios were investigated: obstacles acting like stones that adapt to the ambient temperature, or frost lenses having a constant surface temperature of $0{ }^{\circ} \mathrm{C}$.

\section{Results}

Stable thermal convection occurs when $\mathrm{Nu}>1$ and $\mathrm{Ra}>\mathrm{Ra}_{\mathrm{c}}$. This means that thermal convection is influenced by soil permeability, horizontal groundwater flow, thermal properties of the soil, temperature difference, and the distance between the uppermost and undisturbed groundwater. The results are summarized in Table 1, where the permeability is a function of grain size and "No. of cells" indicates the number of stable convection cells within the control volume. In some cases, stable solutions were not found though $\mathrm{Nu}>1$, which means that part of the heat transport must be a result of convective heat transfer. There were also a number of stable convection patterns for $\mathrm{Nu}<1$.

The current study features:

- The required conditions for thermal groundwater convection to occur

- The required time for fully developed convection patterns to occur

- The influence of obstacles (e.g. frost lenses or stones) on thermal groundwater convection

The permeability was varied to investigate the limits for stable convection in a $5 \cdot 0.5 \mathrm{~m}$ control volume, and permeability values equal to a grain size of $1.5-3 \mathrm{~mm}$ were 
investigated. Stable convection was obtained for permeability values greater than $2.07 \cdot 10^{-9} \mathrm{~m}^{2}$, corresponding to a sand with $1.75-\mathrm{mm}$ grain size (see Table 1, part 2).

Table 1 (part 3) shows the influence of varying depth $(H)$ for $K=2.71 \cdot 10^{-9} \mathrm{~m}^{2}$ (grain size $2 \mathrm{~mm}$ ). Stable convection exists for depths down to $1.0 \mathrm{~m}$, with a decreasing number of cells. For a 1.1-m deep control volume, the $\mathrm{Nu}$ was smaller than 1 , indicating that the temperature gradient was too small to drive the convection. Table 1 (part 4) shows the penetration depth for different permeabilities. For a 3-mm grain size the penetration depth reached $3 \mathrm{~m}$; both 2 and $1.75-\mathrm{mm}$ grain size reached at most $1-\mathrm{m}$ penetration depth, while for $1.5-\mathrm{mm}$ grain size, there was still stable convection at $1.5-\mathrm{m}$ depth.

In a $5 \cdot 0.7-\mathrm{m}$ control volume the effect of three large obstacles was studied for $K=6.0 \cdot 10^{-9} \mathrm{~m}^{2}, T_{\mathrm{H}}=4{ }^{\circ} \mathrm{C}$, and $T_{\mathrm{C}}=0^{\circ} \mathrm{C}, V_{i}=10^{-9} \mathrm{~m} \mathrm{~s}^{-1}$ (see Fig. 4).

The large obstacles forced the convection cells to change size and shape. Obstacles with their own constant wall temperature, $T_{\mathrm{W}}=0{ }^{\circ} \mathrm{C}$, such as a frost lens, generated a different convection pattern than that of an obstacle with the same temperature as the porous media (stones). The transient solution was studied on control volumes $5 \cdot 0.7 \mathrm{~m}$ with and without obstacles. The time required to fully develop a steady convection pattern was about 22 days for each case. This development is shown in Fig. 4 (with obstacles) and Fig. 5 (without obstacles).

\section{Discussion}

The hypothesis that thermally driven groundwater convection could occur as a result of natural cooling of groundwater from 10 to $4{ }^{\circ} \mathrm{C}$ has previously been shown by numerical simulations (Engström and Nordell 2006). The current study shows that such convection also occurs as a result of natural warming of (surface) groundwater from 3 to $4{ }^{\circ} \mathrm{C}$ in medium-grained sands, which could potentially explain why the convection takes place during early summer in the north and during the fall in the south of Sweden. The convection does not reach as deep in the north because the mean temperature of groundwater is close to the temperature of maximum density of water.

An initial horizontal water velocity triggers the start of convection without influencing the temperature-driven groundwater circulation. There are several natural events that initiate similar disturbances, e.g. a fluctuating water table because of rain infiltration, air pressure variation and soil heterogeneities. In the current study, all vertical groundwater movement is density driven and this convection affects all water between the upper and lower limit of the convection cell. This observation indicates how nutrients could infiltrate into groundwater and how important the groundwater temperature is for the infiltration depth. Figure 6 shows a cross section of the convective layer with streamlines and isotherms.

It was shown that obstacles such as frost lenses or stones in the ground change but do not hinder the convection pattern. In the case where obstacles are added, they are purposely shaped in a "difficult" form, in which very few natural obstacles exist. A circular or hexagonal shape would be more forgiving in the simulations. The rectangular shape was supposed to vanquish the convection patterns, but the convection shape was not overpowered by the difficult obstacle shape. Their size was adjusted to be not too small, and not too big. Too small obstacles would not have any significant effect on the convection patterns and too large obstacles would not allow any convection cells. The time required to establish stable convection patterns was about 22 days; thus, a more forgiving shape should decrease the stabilization time.

The Meteonorm model (Meteonorm 2014), an established model to determine climate data anywhere in the world, was used to determine temperature data at selected locations. Monthly mean air temperature records for the north of Sweden (Luleå) show that the ambient air temperature is warmer than the groundwater temperature for 6 months (April-October) of the year. This means that groundwater at
Fig. 4 Numerical steady-state solution for a $5 \cdot 0.7 \mathrm{~m}$ control volume: $V_{\mathrm{i}}=10^{-9} \mathrm{~m} \mathrm{~s}^{-1}, \mathrm{Ra}=61$, $K=6.09 \cdot 10^{-9} \mathrm{~m}^{2}, T_{\mathrm{C}}=0{ }^{\circ} \mathrm{C}$, $T_{\mathrm{H}}=4{ }^{\circ} \mathrm{C}$. a Streamlines of control volume including three obstacles with temperature $T_{0}=0{ }^{\circ} \mathrm{C}, \mathrm{Nu}=0.49$. $\mathbf{b}$ Streamlines of control volume including three obstacles with the same temperature as the surroundings $(\mathrm{Nu}=1.0)$. c Streamlines of undisturbed control volume $(\mathrm{Nu}=1.13)$
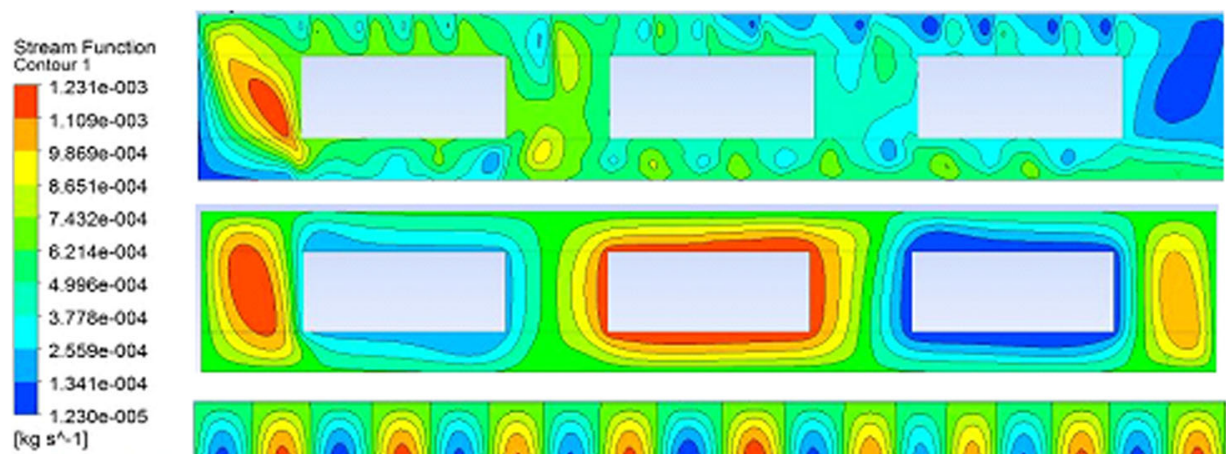

(b)

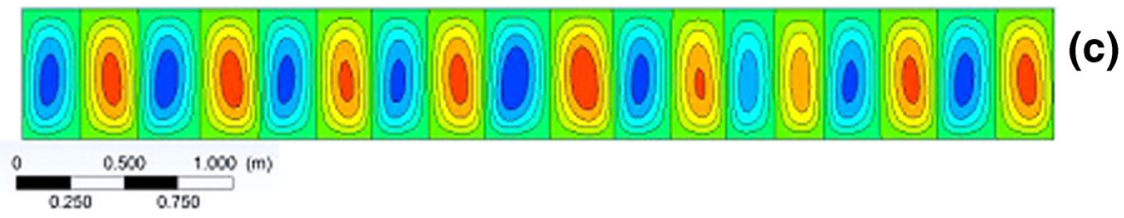


Fig. 5 Numerical transient solution for a $5 \cdot 0.5 \mathrm{~m}$ control volume: $V_{\mathrm{i}}=10^{-9} \mathrm{~m} \mathrm{~s}^{-1}, \mathrm{Ra}=38$, $K=6.09 \cdot 10^{-9} \mathrm{~m}^{2}, T_{\mathrm{C}}=0{ }^{\circ} \mathrm{C}$, $T_{\mathrm{H}}=4{ }^{\circ} \mathrm{C}$. a Convection pattern after 1 day, $\mathrm{Nu}=1.89$; $\mathbf{b}$ Convection pattern after 13 days, $\mathrm{Nu}=0.55$; c Fully developed convection pattern after 22 days, $\mathrm{Nu}=1.36$

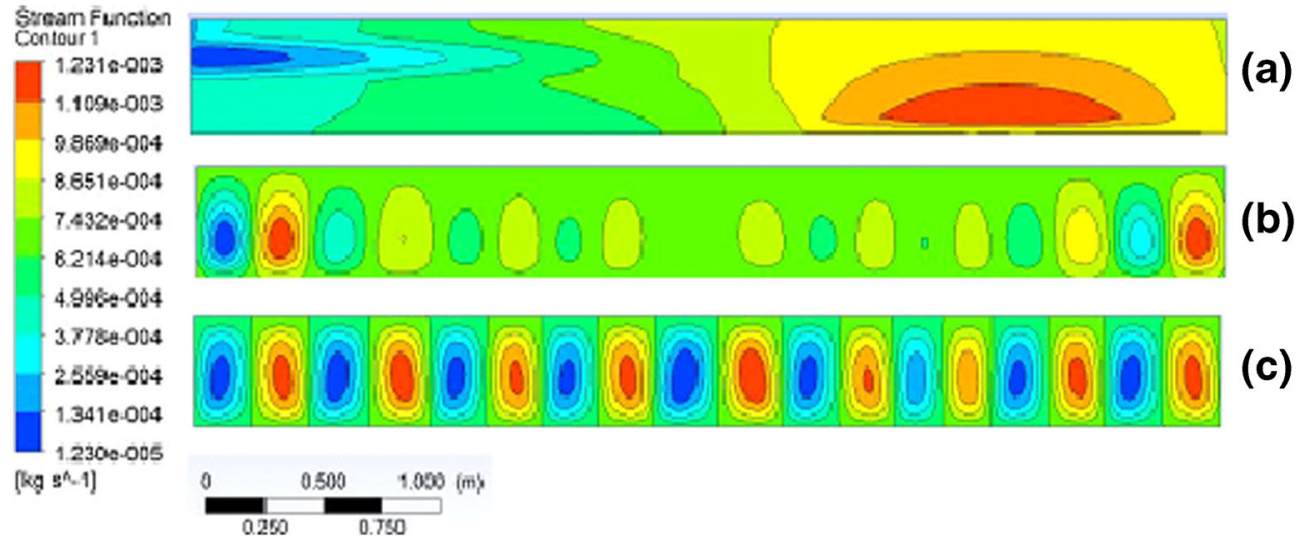

shallow depths will be warmed during half of the year. During the spring, a thin convective layer of groundwater, at a temperature from 4 to $0{ }^{\circ} \mathrm{C}$, moves downwards as the frost thaws. Daily air temperature variation at the surface penetrates approximately $0.2 \mathrm{~m}$ into the ground. This temperature is damped with increasing depth and does not greatly affect the convection (Nordell and Söderlund 1998).

The temperature-driven vertical velocity of the water is in the order of $10^{-6} \mathrm{~m} \mathrm{~s}^{-1}$, when a stable convection pattern is obtained, which means that the water penetrates to a depth of $1 \mathrm{~m}$ within 12 days. Concurrently, the water at $1-\mathrm{m}$ depth flows upwards to close the convection cell.

The smallest required permeability is $K=2.07 \cdot 10^{-9} \mathrm{~m}^{2}$ and corresponds to a coarse sandy soil (grain size of $1.75 \mathrm{~mm}$ ), while agricultural soil normally consists of finer grains; however, since the permeability of a soil is a mean value, there are more or less permeable sections in the soil. Since any flow follows the path of minimum resistance, groundwater will find its way through the more permeable parts of the soil, where the groundwater flow rate will increase and enhance the development of vertical groundwater flow and of course also the convection cells.

In natural systems, thermally driven convection is initiated by different kinds of disturbances - e.g. varying groundwater flow, infiltration of rain and melt water, changing air pressure and permeability variations. These disturbances were not considered in the performed simulations but an initial small horizontal groundwater velocity was introduced to start the convection.

For horizontal groundwater flow to occur, the water table has to be inclined, which is not the case in the present study. Such a gradient enhances vertical water movement, especially in inhomogeneous materials, and it starts secondary currents in the groundwater flow. In that scenario, the groundwater temperature is of little or no importance since the temperature distribution is the same as that outside the calculated section. Infiltration of rain and meltwater, on the other hand, always means vertical groundwater movement that influences the temperature-driven convection.

Bense and Kooi (2004) showed in their study that subtle variations in groundwater flow velocities close to the surface groundwater result in significant temperature anomalies as a result of the interaction of seasonal surface temperature variation and groundwater flow. Therefore, determining horizontal profiles of shallow groundwater temperature could be a tool to assess the small-scale heterogeneity of ground-surface/groundwater interaction.

In a study performed by Bloomfield et al. (2013), seasonal changes in mean annual air temperature at sea level in the UK varies from $8{ }^{\circ} \mathrm{C}$ in the north to $12{ }^{\circ} \mathrm{C}$ in the south. In northern
Fig. 6 Numerical steady-state conceptual solution showing the relation between streamlines and isotherms. a Streamlines; b Isotherms
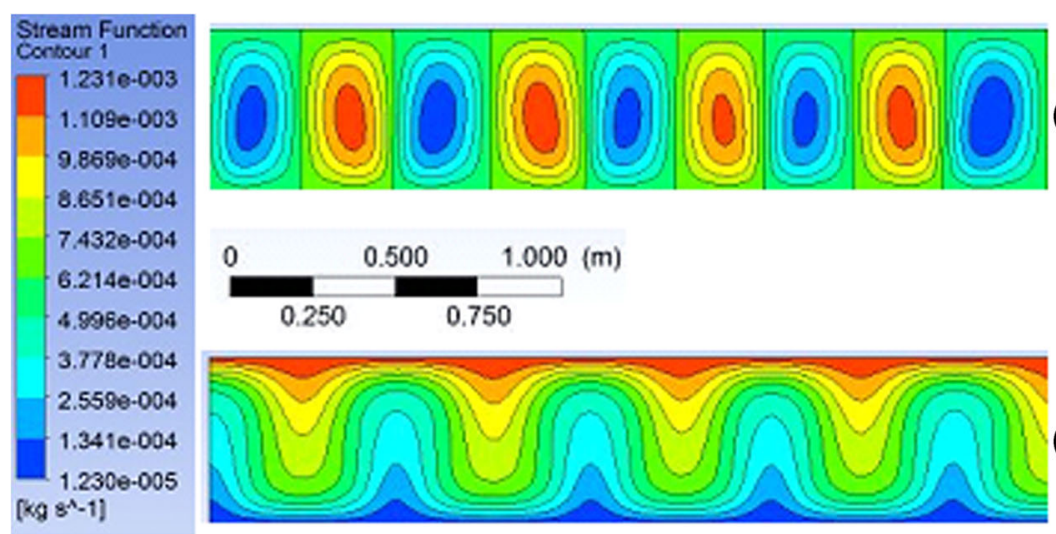

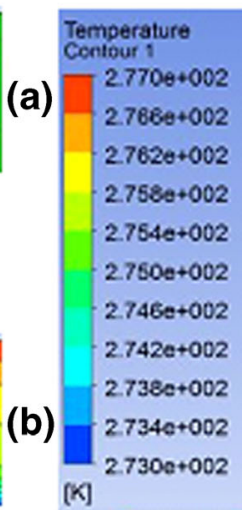


temperate-climate regions, diurnal variations are not generally seen below $1.5 \mathrm{~m}$ depth, whereas seasonal temperature cycles penetrate the ground to depths on the order of $10-15 \mathrm{~m}$ at a rate dependent on the thermal diffusivity of the ground.

Though the diffusion term was less than the convection term, performed calculations (eventually) converged. This idealised solution may not be generally applied in picturing the water flow but indicates that vertical groundwater movements occur. Validation of obtained results should preferably be carried out in a laboratory test since the natural environment includes too many uncontrolled parameters.

The results shown can be helpful in determining when, in the year, to apply fertilizers to the ground in subarctic areas, and to estimate a potential depth to which the nutrients are expected to reach. In traditional studies of convection in groundwater, larger temperature gradients are used over bigger areas.

\section{Conclusions}

The hypothesis, that seasonal temperature variations could initiate and drive thermal groundwater convection in cold climates was supported by numerical simulations, though it was not possible to verify the calculations. The number of convection cells increases with permeability and decreases with the thickness of the control volume in a homogeneous porous medium. Impermeable disturbances in the homogeneous porous media, like stones, also affect the number of convection cells. Convection cells form at $\mathrm{Ra}>15$, provided that an initial disturbance, a horizontal small groundwater velocity, is used.

In some cases, no stable solution was found even with $\mathrm{Nu}>1$, i.e. part of the heat transport must be a result of convective heat transfer. One explanation could be oscillating or propagating convection cells, which would not be seen in steady-state solutions. Since it takes 22 days to establish steady-state groundwater convection, for assumed standard conditions, convection is likely to occur in the north of Sweden. Vertical groundwater movements will exist and will transport nutrients, regardless of whether there are obstacles such as frost lenses or stones in the ground. The obstacles change, but do not hinder the occurring convection pattern in the ground. If there is no stable convection pattern provided, there is still vertical transport of the groundwater, due to seasonal temperature changes in cold climate areas.

Groundwater convection occurs in different seasons of the year depending on whether the groundwater temperature is higher or lower than $4{ }^{\circ} \mathrm{C}$. The size of the convection cells increases with increasing temperature deviation from the maximum density of the groundwater $\left(4^{\circ} \mathrm{C}\right)$. Consequently, the vertical transport of soluble nutrients and fertilizer and, hence, loss from surface soils can be estimated based on simulation of thermally driven convection.

\section{Future work}

The performed simulations show that stable convection was obtained for permeability values greater than $2.07 \cdot 10^{-9} \mathrm{~m}^{2}$, corresponding to sand with a $1.75-\mathrm{mm}$ grain size, which is however considerably greater than that of typical agricultural soils. Although seasonal temperature differences would assist the groundwater convection in such soils, there must also be other explanations to vertical groundwater movements in finegrained soils - other reasons would be unstable groundwater convection or oscillating convection cells, infiltration of rain and melt water, heterogeneous permeability, and pressureinduced convection due to partially melted frost in the ground, i.e. the pressure below the frost layer forces the groundwater to the ground surface.

The Coriolis force, caused by the Earth's rotation, induces secondary currents and is also being studied by the authors and the results are soon to be published. The simulations performed could be verified by monitoring the groundwater temperature in a field test using a three-dimensional grid during a period of time when seasonal groundwater turnover is occurring.

Acknowledgements This study is part of Maria Engström's PhD work. LTU is greatly acknowledged for financial support for the project.

\section{Appendix}

\section{Nomenclature}

$c_{\mathrm{p}} \quad$ Specific heat at constant pressure $\left(\mathrm{J} \mathrm{kg}^{-1} \mathrm{~K}^{-1}\right)$

$D_{\mathrm{p}} \quad$ Grain size $(\mathrm{m})$

$g \quad$ Acceleration of gravity $\left(\mathrm{m} \mathrm{s}^{-2}\right)$

$H \quad$ Depth of control volume (m)

$k$ Thermal conductivity $\left(\mathrm{W} \mathrm{m}^{-1} \mathrm{~K}^{-1}\right)$

$K \quad$ Permeability $\left(\mathrm{m}^{2}\right)$

$L \quad$ Length of control volume (m)

$P \quad$ Pressure $(\mathrm{Pa})$

$Q \quad$ Heat transfer rate $\left(\mathrm{W} \mathrm{m}^{-2}\right)$

Ra Rayleigh number (-)

$\mathrm{Ra}_{\mathrm{c}} \quad$ Critical Rayleigh number (-)

$t \quad$ Time (s)

$T$ Temperature $\left({ }^{\circ} \mathrm{C}\right)$

$T_{0} \quad$ Maximum density temperature $\left({ }^{\circ} \mathrm{C}\right)$

$T_{\mathrm{H}} \quad$ Hot temperature $\left({ }^{\circ} \mathrm{C}\right)$

$T_{\mathrm{C}} \quad$ Cold temperature $\left({ }^{\circ} \mathrm{C}\right)$ 
$T_{\mathrm{W}} \quad$ Frost lens wall temperature $\left({ }^{\circ} \mathrm{C}\right)$

$u \quad$ Horizontal velocity $\left(\mathrm{m} \mathrm{s}^{-1}\right)$

$v \quad$ Vertical velocity $\left(\mathrm{m} \mathrm{s}^{-1}\right)$

$V_{\mathrm{i}} \quad$ Initial velocity $\left(\mathrm{m} \mathrm{s}^{-1}\right)$

$x, y \quad$ Cartesian coordinates in two dimensions

\section{Greek letters}

$\alpha \quad$ Thermal diffusivity $\left(\mathrm{m}^{2} \mathrm{~s}^{-1}\right)$

$\gamma \quad$ Coefficient $\left({ }^{\circ} \mathrm{C}^{-2}\right)$

$\mu \quad$ Dynamic viscosity $\left(\mathrm{kg} \mathrm{m}^{-1} \mathrm{~s}^{-1}\right)$

$\rho \quad$ Density $\left(\mathrm{kg} \mathrm{m}^{-3}\right)$

$\rho_{0} \quad$ Density maximum $\left(\mathrm{kg} \mathrm{m}^{-3}\right)$

$\sigma \quad$ Heat capacity ratio (-)

$v \quad$ Kinematic viscosity $\left(\mathrm{m}^{2} \mathrm{~s}^{-1}\right)$

$\varphi$ Porosity (\%)

\section{Other symbols}

f Fluid related

s Solid related

Open Access This article is distributed under the terms of the Creative Commons Attribution 4.0 International License (http:// creativecommons.org/licenses/by/4.0/), which permits unrestricted use, distribution, and reproduction in any medium, provided you give appropriate credit to the original author(s) and the source, provide a link to the Creative Commons license, and indicate if changes were made.

\section{References}

ANSYS Inc. (2014) ANSYS Fluent. http://www.ansys.com. Accessed 25 October 2014

Bear J (1972) Dynamics of fluids in porous materials. Elsevier, New York

Bense VF, Kooi H (2004) Temporal and spatial variations of shallow subsurface temperature as a record of lateral variations in groundwater flow. J Geophys Res 109:B04103. doi:10.1029/ 2003JB002782

Blake K, Bejan A, Poulikakos D (1984) Natural convection near $4{ }^{\circ} \mathrm{C}$ in a water-saturated porous layer heated from below. Int J Heat Mass Transf 27(12):2355-2364

Bloomfield JP, Jackson CR, Stuart ME (2013) Changes in groundwater levels, temperature and quality in the UK over the 20th century: an assessment of evidence of impacts from climate change. British Geological Survey, Keyworth, UK

Cardenas M et al (2012) Terrestrial smokers: thermal springs due to hydrothermal convection of groundwater connected to surface water. Geophys Res Lett 39(2): doi:10.1029/2011GL050475

Claesson J, Eftring B, Eskilson P, Hellström G (1985) Handbook on thermal analyses, part II heat storage (in Swedish). Report T16-18: 1985, Swedish Council for Building Research, Stockholm
Claesson J, Eftring B, Eskilson P, Hellström G (1985) Handbook on thermal analyses, part I general (in Swedish). Report T16-18:1985, Swedish Council for Building Research, Stockholm

Ene H, Polisevski D (1987) Thermal flow in porous media. Riedel, Dordrecht, The Netherlands

Engström M, Nordell B (2006) Seasonal groundwater turnover. Nord Hydrol 37(1):31-39

Franks F (1972) Water: a comprehensive treatise, vol 1-the physics and physical chemistry of water. Plenum, New York

Goren S (1966) On free convection in water at $4{ }^{\circ} \mathrm{C}$. Chem Eng Sci 21: 515-518

Hellström G, Tsang CF, Claesson J (1988) Buoyancy flow at a two-fluid interface in a porous medium analytical studies. Water Resour Res 24(4):493-506. doi:10.1029/WR024i004p00493

Kirilin G (2010) Modeling the impact of global warming on water temperature and seasonal mixing regimes in small temperate lakes. Boreal Environ Res 15:279-293

Krol M, Sleep B, Johnson R (2014) An analysis of a mixed convection associated with thermal heating in contaminated porous media. Sci Total Environ 15:7-17

Kundu P (1990) Fluid mechanics. Academic, Cambridge

Kyllmar K (2004) Nitrogen leaching in small agricultural catchments modelling and monitoring for assessing state, trends and effects of counter-measures. PhD Thesis, Swedish University of Agricultural Sciences, Uppsala, Sweden, $485 \mathrm{pp}$

Lapwood E (1948) Convection of a fluid in a porous medium. Math Proc Camb Philos Soc 44:508-521. doi:10.1017/S030500410002452X

Meteonorm (2014) http://www.meteotest.ch/en/. Accessed 25 October 2014

Moore D, Weiss N (1973) Nonlinear penetrative convection. J Fluid Mech 61(3):553-581

Nield D, Bejan A (1999) Convection in porous media. Springer, Berlin

Nield D, Kuznetsov A (2010) The onset of convection in a heterogeneous porous medium with transient temperature profile. Transp Porous Media 85:691-702. doi:10.1007/s11242-010-9586-8

Nordell B, Söderlund M (1998) Solvärme och Värmelagring [Solar heat and heat storage]. LTU, Luleå, Sweden

Pestov I (2000) Numerical techniques for simulating groundwater flow in the presence of temperature gradients. J Aust Math Soc

Prasad V, Kulacki F (1984) Natural convection in a rectangular porous cavity with constant heat flux on one vertical wall. J Heat Transf 106(1):152-157

Prasad A, Simmons C (2003) Unstable density-driven flow in heterogeneous porous media: a stochastic study of the elder [1967b] "short heater" problem. Water Resour Res 39(1):1007. doi:10.1029/ 2002WR001290

Rehbinder G, Gustafsson G, Thunvik R (1995) Grundvattenströmningens teori [Theory of groundwater flow]. KTH, Stockholm

Simmons C, Fenstemaker T, Sharp J (2001) Variable-density groundwater flow and solute transport in heterogeneous porous media: approaches, resolutions and future challenges. J Contam Hydrol 52:245-275

Straus JM, Schubert G (2012) Thermal convection of water in a porous medium: effects of temperature- and pressure-dependent thermodynamic and transport properties. J Geophys Res 82:325-333

Vadaz P, Olek S (1999) Weak turbulence and chaos for low Prandtl number gravity driven convection in porous media. Transp Porous Media 37:69-91 